\title{
Irrigation Water Quality Status of Madanapalle Block in Chittor district, Andhra Pradesh, India
}

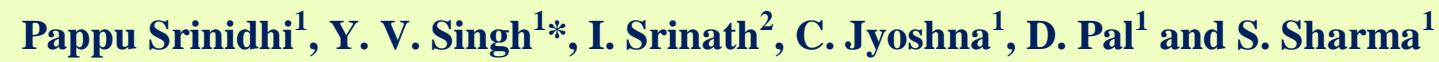 \\ ${ }^{1}$ Department of Soil Science and Agricultural Chemistry, Institute of Agricultural Sciences, \\ Banaras Hindu University, Varanasi- 221 005, Uttar Pradesh, India \\ ${ }^{2}$ Department of Soil Science and Agricultural Chemistry, Sam Higginbottom University of \\ Agriculture, Technology and Sciences, Prayagraj-211007, Uttar Pradesh, India \\ *Corresponding author
}

\section{Keywords}

Water quality, Primary parameters, Secondary parameters, Irrigation water quality index

\section{Article Info}

Accepted:

26 May 2020

Available Online:

10 June 2020

\begin{abstract}
A B S T R A C T
The concentration of dissolved constituents in water determines its quality for irrigation use. Quality of irrigation water is an important consideration in an irrigated area. In the present study irrigation water quality of Madanapalle town was analysed by selecting eight different villages and from each village 3 water samples were collected and analysed for primary parameters such as $\mathrm{pH}$, Electrical conductivity, alkalinity, total hardness, potassium, chloride and sodium in order to understand the irrigation water quality index. The secondary water parameters such as sodium adsorption ratio, soluble sodium percentage, Kelly's ratio, residual sodium carbonate and Permeability index were calculated from the data obtained from primary parameters. The results stated that the $\mathrm{pH}$ of the samples ranges from 6.21-8.34 and EC is ranging between 0.50-4.32 $\mathrm{dSm}^{-1}$. Sodium and potassium content of water ranges from $1.39-4.78$ and $0-0.51 \mathrm{MeqL}^{-1}$ respectively. Whereas calcium and magnesium (calcium + magnesium) ranges from 4.8-58.4 $\mathrm{MeqL}^{-1}$. Chloride and bicarbonate content ranged from 2.4-30 and $1.4-4 \mathrm{MeqL}^{-1}$. Accordingly irrigation water quality index was found that $8.33 \%$ of the samples were found sustainable, $62.50 \%$ of the samples were found slightly sustainable and $25.00 \%$ of the samples found unsustainable. The results strongly recommend that still improvement has to be done to improve the quality of irrigation water mainly by improving the cultivation practices.
\end{abstract}

\section{Introduction}

Water quality for agricultural purposes is determined based on the effect of water on the quality and yield of the crop and effect on characteristics changes in soil (FAO, 1985). Generally quality of irrigation water describes the concentration and state of the organic and inorganic materials suspended in water. The determination of the quality is done in In-situ measurements and also by examining the samples in laboratory. The water used for irrigation can vary greatly depending on the type and the quantity of the salts dissolved. Generally the salts in the irrigation water originate from different sources which include 
weathering of the rocks, dissolution lime, gypsum and other minerals, sea water intrusion, etc. when such water is applied to the plant there will be an increase in osmotic potential and make it difficult for the roots to absorb the water from the soil and also as the water evaporates the salts get accumulates on surface of the soil as the white crust. Therefore water quality testing plays an important role in monitoring the plant life and also forms the important part of the environmental monitoring. According to (Chapman et al., 1996) water quality describes physical, chemical and biological components of water that has been extensively examined and reported for drinking water. Suitability of water in a particular place depends on groundwater geochemistry because each ground water system has different chemical composition any alteration depends upon several factors such as rock-water intrusion, mineral dissolution, soil-water intrusion and anthropogenic activities (Chaudhary et al., 2018). The quality of irrigation water depends primarily on the total amount of salt present and the proportion of $\mathrm{Na}+$ to other cation and certain other parameters (Shashi Kant et al., 2015). The problems related to water quality is high in areas where there is dense population, industrialized areas and having shallow water tables. Based on US salinity Laboratory staff (1954) the soil problems related to quality of irrigation water include salinity, water infiltration, toxicity and miscellaneous problems. The present work deals with irrigation water quality status of Madanapalle block of Chittor district, Andhra Pradesh.

\section{Materials and Methods}

\section{Physiography and climate of study area}

Madanapalle is a town in Chittor district of the Indian state of Andhra Pradesh. It comes under municipality of Madanapalle mandal and Madanapalle revenue division. The area shows the ecological features of Deccan Plateau, Eastern Ghats and Western Ghats as it is located at the tri-junction of these three ecological features. The area is surrounded with the broken hill ranges with forestlands on ridges, farmlands and waste lands which are found on the lower slopes with numerous irrigation tanks. There are total of 21 villages in this mandal.

The place is located at an average elevation of $695 \mathrm{~m}$ above the mean sea level and it is located at $13.55^{\circ} \mathrm{N}$ and $78.50^{\circ} \mathrm{E}$. The place shows tropical type of climate with pleasant mild warm summers with an average temperature of $30-35^{\circ} \mathrm{C}$ and during summers the temperature do not exceed to $40^{\circ} \mathrm{C}$. Winters in Madanapalle are cold with temperature between $7-15^{\circ} \mathrm{C}$. Summer season lasts from March to June with rainy season in June followed by winter which lasts upto February.

\section{Analysis of physico-chemical parameters}

The collected of water samples were analysed for major Physical and Chemical water quality parameter like $\mathrm{pH}$, Electrical conductivity, potassium, sodium, calcium+magnesium, carbonate, bicarbonate and chloride by following standard methods (APHA, 1992). The $\mathrm{pH}$ of the water samples were analysed by using $\mathrm{pH}$ meter whereas conductivity was measured by using pen EC meter and was expressed in $\mathrm{dSm}^{-1}$.

Potassium and sodium were measured by using flame photometer instrument which was calibrated by using 100ppm and 50ppm potassium chloride $(\mathrm{KCl})$ and sodium chloride solution $(\mathrm{NaCl})$. Calcium+magnesium in water samples were determined by complex metric titration method using $0.01 \mathrm{~N}$ EDTA solution and Erichrome Black-T as indicator 
where the initial colour light pink changes to blue. Alkalinity was determined by the Acidimetric titration method using $0.05 \mathrm{~N}$ sulphuric acid solution and phenolphthalein as indicator used for determination of carbonate where colour changes to pink indicate the presence of carbonate whereas methyl orange is used as indicator for determination of bicarbonate where initial colour yellow changes to final colour rose red.

Calcium in water samples were determined by using 0.01N EDTA solution and Muroxide as indicator through titration method where the initial colour pink changes to purple and chloride was determined by the Argentometric (Mohr's) method. The secondary water quality parameters include SAR, RSC, SSP, KR and PI were analyzed from primary water parameters.

\section{Sodium adsorption ratio (SAR)}

SAR is a measure of the amount of sodium $\left(\mathrm{Na}^{+}\right)$relative to calcium $\left(\mathrm{Ca}^{2+}\right)$ and magnesium $\left(\mathrm{Mg}^{2+}\right)$ in the water. (Richards) calculated the sodium adsorption ratio by the following formula where the concentration of all ions is in Meq $\mathrm{L}^{-1}$.

$\mathrm{SAR}=\frac{N a}{\sqrt{C a+M g / 2}}$

\section{Residual sodium carbonate (RSC)}

Residual sodium bicarbonate is an index which is used to measure the alkalinity hazard in water. The RSC is calculated by using the following formula where the concentrations of all ions are in $\mathrm{Meq} \mathrm{L}^{-1}$ (Eaton, 1950).

$\operatorname{RSC}\left(\mathrm{Meq} \mathrm{L}^{-1}\right)=\left(\mathrm{CO}_{3}{ }^{2-}+\mathrm{HCO3}^{-}\right)-\left(\mathrm{Ca}^{2+}+\right.$ $\mathrm{Mg}^{2+}$ )

\section{Soluble sodium percentage (SSP)}

Soluble sodium percentage gives a clear idea about sodium content which is important for studying sodium hazard. The SSP is calculated by using the following formula where the concentrations of all ions are in Meq L ${ }^{-1}$ (Todd, 1980).

$\mathrm{SSP}=\frac{\mathrm{Na} \times 100}{\mathrm{Ca}+\mathrm{Mg}+\mathrm{Na}}$

If SSP is less than 50 it indicated good quality of water. If the values are higher than 50 indicate it is unsafe for irrigation (USDA, 1954).

\section{Kelly's ratio $(\mathrm{KR})$}

Suitability of water for irrigation purposes is also assessed on the bases of Kelly's ratio (Kelly, 1951). Ratio of sodium verses calcium and of sodium verses magnesium is used as Kelly's ratio. Kelly's ratio was calculated by using the following expression. Where, concentrations are expressed in Meq $\mathrm{L}^{-1}$.

$\mathrm{KR}=\frac{\mathrm{Na}^{+}}{\mathrm{Ca}^{2+}+\mathrm{Mg}^{2+}}$

Groundwater having Kelly's ratio more than one is considered not-suitable for irrigation purposes and ground water having Kelly's ratio less than one is considered suitable for irrigation (Karanth, 1987).

\section{Permeability index (PI)}

The permeability is affected by consistent use of irrigation water which increases the presence of sodium, calcium, magnesium and bicarbonate in the soil (Chandu et al., 1995). The permeability index (PI) is used to measure the suitability of water for irrigation purpose when compared with the total ions in Meq $\mathrm{L}^{-1}$.

$\mathrm{PI}=\frac{\mathrm{Na}+\sqrt{\mathrm{HCO}} 3}{\mathrm{Ca}+\mathrm{Mg}+\mathrm{Na}} \times 100$ 


\section{Irrigation Water Quality Index (IWQI)}

The various indices of water quality were derived from the primary parameters of water quality. Irrigation water quality refers to its suitability for agricultural use. The requirements for irrigation water quality could differ from one field to the other depending on the cultivated crop pattern as well as the regional soil and climatological conditions (Babiker et al., 2007). IWQI model was applied on the data. This model developed by (Meireles et al., 2010). In the first step, selection of parameters in this we have to study the Indian standard $(B I S, 1991)$ for drinking water specification.

\section{Computation of WQI}

The WQI is computed following the three steps

1. Assigning of weight $\left(\mathrm{w}_{\mathrm{i}}\right)$ to the selected water parameters (e.g. $\mathrm{pH}, \mathrm{HCO}_{3}, \mathrm{Cl}, \mathrm{EC}, \mathrm{Na}$, $\mathrm{K}$.....etc) according to their relative importance in the overall quality of water.

2. Computation of relative weight $\left(\mathrm{W}_{\mathrm{i}}\right)$ of the chemical parameter using the following equation

$\mathrm{W}_{\mathrm{i}}=\mathrm{w}_{\mathrm{i}} / \Sigma \mathrm{w}_{\mathrm{i}}(\mathrm{i}=1$ to $\mathrm{n})$

Where, $\mathrm{W}_{\mathrm{i}}$ is the relative weight

$\mathrm{w}_{\mathrm{i}}=$ Weight of each parameter

$\mathrm{n}=$ Number of parameters

3. Assigning of a quality rating scale $\left(\mathrm{q}_{\mathrm{i}}\right)$ for each parameter, as below:

$\mathrm{q}_{\mathrm{i}}=\left(\mathrm{C}_{\mathrm{i}} / \mathrm{S}_{\mathrm{i}}\right) \times 100$

Where, $q_{i}=$ quality rating

$\mathrm{C}_{\mathrm{i}}=$ Concentration of each chemical parameter in each water sample in $\mathrm{mg} / \mathrm{l}$ $\mathrm{S}_{\mathrm{i}}=$ Guide line value given in BIS 1991
For computation of WQI, the sub-index (SI) is first determined for each chemical parameter, given below:

$\mathrm{Sl}_{\mathrm{i}}=\mathrm{W}_{\mathrm{i}} \times \mathrm{q}_{\mathrm{i}}$

$\mathrm{WQI}=\Sigma \mathrm{Sl}_{\mathrm{i}} 1-\mathrm{n}$

Where, $\mathrm{Sl}_{\mathrm{i}}=$ sub index of $\mathrm{i}^{\text {th }}$ parameter

$\mathrm{W}_{\mathrm{i}}=$ Relative weight of $\mathrm{i}^{\text {th }}$ parameter

$\mathrm{q}_{\mathrm{i}}=$ Rating based on concentration of $\mathrm{i}^{\text {th }}$ parameter

$\mathrm{n}=$ Number of chemical parameters.

\section{Results and Discussion}

The results of the physico-chemical properties of irrigation water samples from different villages of Madanapalle is a town in Chittor district are given in the table 1 .

The values of various parameters of water samples were analyzed and correlated. The $\mathrm{pH}$ of the water samples ranges from 6.21 to 8.34 with a mean value of 6.99 . Out of the total samples collected only 2 samples $(8.33$ $\%$ ) has shown moderately suitable for irrigation while the rest $91.6 \%$ of the samples suitable for irrigation purpose. This clearly states that the water samples are neutral to slightly alkaline in nature which conclude its suitability for irrigation purpose. Higher $\mathrm{pH}$ is server to crops (Ayers and Westcot, 1985) and reduces the effectiveness of some nitrogenous fertilizers through irrigation (Bryan et al., 2007). Similar results were reported with (Gummadi, 2015) in studying with irrigation water of coastal Andhra Pradesh. The electrical conductivity of the water samples ranged between 0.50 to 4.32 $\mathrm{dSm}^{-1}$ with the mean value of $1.62 \mathrm{dSm}^{-1}$. Out of total samples collected $16.6 \%$ of the samples were suitable for irrigation, $62.50 \%$ of the samples were moderately suitable for irrigation and $20.8 \%$ of the samples are not suitable for irrigation. This clearly shows that 
the water samples of Madanapalle town are in moderate range of electrical conductivity for its use in irrigation. Higher EC concentration in water means high amount of total dissolved which causes water to lose its portability and reduces the solubility of oxygen in water (Kumar et al., 2011).

The present investigation has shown that the groundwater from the different villages of Madanapalle block is free from carbonate concentration. The bicarbonate concentrations of the samples range between 1.4 to $4 \mathrm{Meq} \mathrm{L}$ ${ }^{1}$ with the average value of $2.58 \mathrm{Meq} \mathrm{L}^{-1}$. Out of total samples collected it is reported that $100 \%$ of the samples were moderately range for its use in irrigation.

Similar results were reported with (Acharya, 2010) Gujarat. The data on chloride content of groundwater samples ranges from 2.4 to 30 Meq $\mathrm{L}^{-1}$ with a mean value of $10.6 \mathrm{Meq}^{-1}$. Out of total samples collected $37.5 \%$ of the samples are in suitable range, $33.3 \%$ of the samples have shown moderately suitable range and $29.1 \%$ of samples have shown not suitable for irrigation.

The calcium plus magnesium of groundwater samples ranges from 4.8 to $58.4 \mathrm{Meq} \mathrm{L}^{-1}$ with a mean value of $21.7 \mathrm{Meq} \mathrm{L}^{-1}$. The highest desirable limit of total hardness is $6.0 \mathrm{Meq} \mathrm{L}^{-1}$ as per the guidelines (ICMR, 1975).Out of total samples collected only one sample i.e. sample no: 6 is less than $6.0 \mathrm{Meq} \mathrm{L}^{-1}$ and shown suitable. According to the guideline given by ICMR the irrigation water of Madanapalle town based on calcium concentration shows not suitable for its use in irrigation.

The potassium content of groundwater samples ranges from 0 to $0.51 \mathrm{Meq} \mathrm{L}^{-1}$ with a mean value of $0.03 \mathrm{Meq} \mathrm{L}^{-1}$. The guideline range for potassium in water is $0-20 \mathrm{Meq} \mathrm{L}^{-}$ ${ }^{1}$ (FAO, 1994). According to this data the potassium content in ground water samples of
Madanapalle town are moderately suitable for its use in irrigation. The sodium concentration in groundwater samples ranges from 1.39 to $4.78 \mathrm{Meq} \mathrm{L}^{-1}$ with a mean value of $2.53 \mathrm{Meq}$ $\mathrm{L}^{-1}$. Out of total samples collected $70.8 \%$ of the samples have shown suitable for irrigation and $29.1 \%$ of the samples has shown moderately suitable for irrigation.

Irrigation water quality of index of samples ranges from 81.2 - 519.6 with a mean value of 225.5. Out of total number of soil samples $62.5 \%$ of the samples are in poor range for irrigation, $4.16 \%$ only one sample is under very poor range for irrigation, $25 \%$ of the samples are unsuitable for irrigation and $8.33 \%$ of samples are in good range for its use for irrigation purpose. Due to presence of high calcium and magnesium i.e. total harness caused high water quality index in water (Table 2).

\section{Correlation between water quality parameters}

The correlation between the water quality parameters were given in the Table 3 . The $\mathrm{pH}$ of the water is positively non-significantly correlated with potassium $(\mathrm{r}=0.149)$, bicarbonate $(\mathrm{r}=0.194)$, sodium adsorption ratio $(r=0.023)$, Kelly's ratio $(r=0.010)$, permeability index $(\mathrm{r}=0.080)$, soluble sodium percentage $(r=0.049)$. The EC of the water is negatively none significantly correlated with permeability index $(r=-018)$ and positively non-significantly correlated with sodium $(\mathrm{r}=0.981)$, RSC $(\mathrm{r}=0.0019)$, potassium (0.204). The bicarbonate content of the water is positively significantly correlated with sodium adsorption ratio $(r=0.429)$ while positively non-significantly correlated with chloride $(r=0.724)$, Kelly's ratio $(r=0.001)$, RSC ( $r=0.020)$ and negatively nonsignificantly correlated with permeability index $(\mathrm{r}=-0.088)$, soluble sodium percentage $(\mathrm{r}=-0.038)$. 
Table.1 Water quality parameters of different villages of Madanapalle town of Chittor district in Andhra Pradesh

\begin{tabular}{|c|c|c|c|c|c|c|c|c|c|c|c|c|c|c|c|}
\hline $\begin{array}{c}\text { Sample } \\
\text { no }\end{array}$ & pH & $\begin{array}{c}\mathrm{EC} \\
\left(\mathrm{dSm}^{-1}\right)\end{array}$ & $\begin{array}{c}\mathrm{Ca}+\mathrm{Mg} \\
\left(\mathrm{Meq} \mathrm{L}^{-1}\right)\end{array}$ & $\begin{array}{c}\text { Ca } \\
\left(\operatorname{Meq~L}^{-1}\right)\end{array}$ & $\begin{array}{c}\mathrm{K}^{+} \\
\left(\operatorname{Meq}^{-1} \mathbf{L}^{-1}\right)\end{array}$ & $\begin{array}{c}\mathrm{Na}^{+} \\
\left(\mathrm{Meq}^{-1}\right)\end{array}$ & $\begin{array}{c}\mathrm{Cl}^{-} \\
\left(\mathrm{Meq} \mathrm{L}^{-1}\right)\end{array}$ & $\begin{array}{c}\mathrm{CO}_{3}{ }^{2-} \\
\left(\mathrm{Meq} \mathrm{L}^{-1}\right)\end{array}$ & $\begin{array}{c}\mathrm{HCO}_{3} \\
\left(\operatorname{Meq~L} L^{-1}\right)\end{array}$ & SAR & PI & KR & SSP & RSC & IWQI \\
\hline $\mathbf{W}_{1}$ & 6.21 & 0.78 & 17.2 & 12.4 & 0.000 & 1.52 & 4.0 & 0 & 2.0 & 0.52 & 15.6 & 0.09 & 8.13 & -15.2 & 129.3 \\
\hline $\mathbf{W}_{2}$ & 6.59 & 1.13 & 14.2 & 12.2 & 0.051 & 2.08 & 5.2 & 0 & 2.0 & 0.78 & 21.5 & 0.15 & 12.8 & -12.2 & 154.3 \\
\hline $\mathbf{W}_{3}$ & 7.07 & 1.22 & 28.2 & 15.8 & 0.051 & 2.34 & 4.0 & 0 & 2.8 & 0.63 & 13.1 & 0.08 & 7.69 & -23.6 & 491.7 \\
\hline $\mathbf{W}_{4}$ & 6.68 & 1.15 & 25.8 & 14.2 & 0.051 & 2.04 & 4.8 & 0 & 2.2 & 0.57 & 12.6 & 0.08 & 7.34 & -21.0 & 194.4 \\
\hline $\mathrm{W}_{5}$ & 7.38 & 1.07 & 20.6 & 20.2 & 0.051 & 2.08 & 4.0 & 0 & 2.6 & 0.65 & 16.3 & 0.10 & 9.20 & -24.4 & 373.3 \\
\hline$W_{6}$ & 6.98 & 1.00 & 4.8 & 3.8 & 0.051 & 1.95 & 4.0 & 0 & 2.2 & 1.26 & 50.9 & 0.41 & 28.9 & -4.40 & 487.3 \\
\hline $\mathrm{W}_{7}$ & 6.94 & 0.84 & 22.8 & 15.2 & 0.025 & 1.65 & 2.4 & 0 & 1.8 & 0.49 & 12.2 & 0.07 & 6.76 & -6.00 & 181.1 \\
\hline$W_{8}$ & 7.07 & 0.93 & 26.4 & 18.8 & 0.025 & 1.73 & 4.0 & 0 & 2.0 & 0.48 & 11.2 & 0.07 & 6.18 & -6.80 & 168.8 \\
\hline$W_{9}$ & 6.95 & 0.94 & 6.6 & 6.2 & 0.051 & 1.78 & 3.6 & 0 & 2.2 & 0.98 & 38.9 & 0.27 & 21.2 & -24.6 & 115.0 \\
\hline$W_{10}$ & 7.95 & 0.61 & 7.4 & 6.8 & 0.000 & 1.43 & 4.0 & 0 & 1.4 & 0.75 & 29.6 & 0.19 & 16.2 & -55.0 & 144.8 \\
\hline$W_{11}$ & 6.70 & 0.50 & 8.2 & 4.4 & 0.000 & 1.39 & 3.6 & 0 & 1.4 & 0.69 & 26.8 & 0.17 & 14.5 & -8.00 & 168 \\
\hline$W_{12}$ & 6.48 & 1.08 & 27.0 & 10.0 & 0.025 & 1.82 & 4.8 & 0 & 2.4 & 0.50 & 11.7 & 0.07 & 6.33 & -54.8 & 114.8 \\
\hline$W_{13}$ & 6.80 & 3.46 & 58.4 & 17.8 & 0.025 & 4.34 & 23.2 & 0 & 3.4 & 0.80 & 9.87 & 0.07 & 6.93 & -25.4 & 93.4 \\
\hline$W_{14}$ & 6.95 & 3.36 & 12.0 & 8.0 & 0.051 & 4.34 & 22.8 & 0 & 4.0 & 1.77 & 38.8 & 0.36 & 20.6 & -18.0 & 81.2 \\
\hline$W_{15}$ & 6.98 & 3.32 & 58.2 & 15.8 & 0.051 & 4.17 & 25.6 & 0 & 3.4 & 0.77 & 9.65 & 0.07 & 6.69 & -2.60 & 176.4 \\
\hline$W_{16}$ & 6.83 & 2.74 & 40.2 & 39.8 & 0.025 & 3.30 & 21.2 & 0 & 2.8 & 0.76 & 11.4 & 0.08 & 7.60 & -37.4 & 405.2 \\
\hline$W_{17}$ & 6.86 & 3.93 & 13.4 & 11.8 & 0.025 & 4.78 & 30.0 & 0 & 3.4 & 1.85 & 36.4 & 0.36 & 26.3 & -10.0 & 442.9 \\
\hline$W_{18}$ & 6.80 & 4.32 & 31.0 & 29.0 & 0.051 & 4.78 & 28.0 & 0 & 4.0 & 1.21 & 18.9 & 0.15 & 13.3 & -27.0 & 519.6 \\
\hline$W_{19}$ & 8.22 & 1.30 & 16.4 & 8.6 & 0.051 & 2.69 & 4.4 & 0 & 3.2 & 0.94 & 23.4 & 0.16 & 14.1 & -13.2 & 173.2 \\
\hline $\mathbf{W}_{20}$ & 7.25 & 1.58 & 22.4 & 7.2 & 0.025 & 3.0 & 8.0 & 0 & 3.8 & 0.90 & 19.4 & 0.13 & 11.8 & -18.6 & 217.0 \\
\hline $\mathbf{W}_{21}$ & 6.65 & 1.12 & 5.8 & 5.2 & 0.025 & 2.43 & 6.0 & 0 & 1.4 & 1.43 & 43.9 & 0.42 & 29.5 & -4.40 & 130.7 \\
\hline $\mathbf{W}_{22}$ & 8.34 & 0.96 & 21.0 & 14.6 & 0.051 & 2.00 & 7.2 & 0 & 2.8 & 0.62 & 15.9 & 0.10 & 8.70 & -18.2 & 170.7 \\
\hline $\mathbf{W}_{23}$ & 6.21 & 0.58 & 24.6 & 10.0 & 0.051 & 1.47 & 6.4 & 0 & 1.8 & 0.42 & 10.8 & 0.06 & 5.67 & -22.8 & 137.5 \\
\hline $\mathbf{W}_{24}$ & 7.08 & 0.87 & 10.4 & 8.4 & 0.025 & 1.65 & 10.4 & 0 & 3.0 & 0.72 & 28.0 & 0.16 & 13.7 & -7.40 & 142.9 \\
\hline Mean & 6.99 & 1.62 & 21.79 & 13.17 & 0.03 & 2.53 & 10.60 & 0 & 2.58 & 0.85 & 21.9 & 0.16 & 13.1 & -19.2 & 225.5 \\
\hline S.D & 0.53 & 1.17 & 14.41 & 8.15 & 0.018 & 1.13 & 9.17 & 0 & 0.81 & 0.38 & 12.0 & 0.11 & 7.74 & 14.0 & 140.2 \\
\hline CV (\%) & 7.61 & 190.4 & 66.1 & 61.8 & 51.6 & 44.57 & 91.1 & 0 & 31.3 & 45.6 & 54.9 & 70.8 & 58.7 & -73.3 & 62.1 \\
\hline Range & $\begin{array}{l}6.21- \\
8.34\end{array}$ & $\begin{array}{c}0.50- \\
4.32\end{array}$ & 4.8-58.4 & 3.8-39.8 & $0-0.51$ & $1.39-4.78$ & 2.4-30 & 0 & $1.4-4$ & $\begin{array}{c}0.42- \\
1.85\end{array}$ & $\begin{array}{c}9.65- \\
50.9\end{array}$ & $\begin{array}{c}0.06- \\
0.42\end{array}$ & $\begin{array}{l}5.67- \\
29.5\end{array}$ & $\begin{array}{c}-55-- \\
2.60\end{array}$ & $\begin{array}{l}81.2- \\
519.6\end{array}$ \\
\hline
\end{tabular}

NOTE: $\mathrm{SAR}=$ Sodium adsorption ratio, $\mathrm{RSC}=$ Residual sodium carbonate, $\mathrm{KR}=$ Kelly's ratio $\mathrm{SSP}=\mathrm{Soluble}$ sodium percentage,

$\mathrm{PI}=$ Permeability index, IWQI=Irrigation water quality i 
Table.2 Water Quality Classification Based on WQI Value

\begin{tabular}{|l|c|c|c|l|}
\hline \multicolumn{1}{|c|}{ WQI } & Water quality status & No. of samples (IWQI) & \% of the samples & \multicolumn{1}{|c|}{ Sustainable state } \\
\hline $\mathbf{5 0}$ & Excellent & 0 & $0 \%$ & Sustainable \\
\hline $\mathbf{5 0 - 1 0 0}$ & Good & 2 & $8.33 \%$ & Sustainable \\
\hline $\mathbf{1 0 0 - 2 0 0}$ & Poor & 15 & $62.50 \%$ & Slightly Unsustainable \\
\hline $\mathbf{2 0 0 - 3 0 0}$ & Very poor & 1 & $04.16 \%$ & Unsustainable \\
\hline $\mathbf{3 0 0}$ & Unsuitable & 6 & $25.00 \%$ & Highly Unsustainable \\
\hline
\end{tabular}

Table.3 Correlation between water quality parameters of Madanapalle block of Chittor district in Andhra Pradesh

\begin{tabular}{|c|c|c|c|c|c|c|c|c|c|c|c|c|c|c|}
\hline Parameters & pH & EC & $\mathrm{Na}^{+}$ & $\mathbf{K}^{+}$ & $\mathrm{Ca}^{2+}$ & $\mathrm{Mg}^{2+}$ & $\mathrm{Ca}+\mathrm{Mg}$ & $\mathrm{HCO}_{3}$ & $\mathrm{Cl}^{-}$ & SAR & PI & KR & SSP & RSC \\
\hline pH & 1 & & & & & & & & & & & & & \\
\hline EC & -0.097 & 1 & & & & & & & & & & & & \\
\hline $\mathrm{Na}^{+}$ & -0.022 & 0.981 & 1 & & & & & & & & & & & \\
\hline $\mathbf{K}^{+}$ & 0.149 & 0.204 & 0.249 & 1 & & & & & & & & & & \\
\hline $\mathrm{Ca}^{2+}$ & -0.058 & $0.470^{*}$ & 0.382 & 0.121 & 1 & & & & & & & & & \\
\hline $\mathrm{Mg}^{2+}$ & -0.114 & 0.318 & 0.343 & 0.098 & 0.064 & 1 & & & & & & & & \\
\hline $\mathrm{Ca}+\mathrm{Mg}$ & -0.123 & $0.517^{*}$ & $0.487^{*}$ & 0.146 & $0.616^{*}$ & 0.825 & 1 & & & & & & & \\
\hline $\mathrm{HCO}_{3}$ & 0.194 & 0.776 & 0.813 & 0.388 & 0.309 & 0.311 & $0.420^{*}$ & 1 & & & & & & \\
\hline $\mathrm{Cl}^{-}$ & -0.121 & 0.965 & 0.931 & 0.118 & $0.450^{*}$ & 0.315 & $0.503^{*}$ & 0.724 & 1 & & & & & \\
\hline SAR & 0.023 & $0.593^{*}$ & $0.647^{*}$ & 0.150 & -0.182 & -0.254 & -0.304 & $0.429^{*}$ & $0.559^{*}$ & 1 & & & & \\
\hline PI & 0.080 & -0.018 & 0.028 & 0.005 & $-0.568^{*}$ & $-0.525^{*}$ & -0.736 & -0.088 & -0.016 & 0.748 & 1 & & & \\
\hline KR & 0.010 & 0.150 & 0.204 & 0.047 & $-0.478^{*}$ & $-0.452^{*}$ & $-0.627^{*}$ & 0.001 & 0.139 & 0.862 & 0.965 & 1 & & \\
\hline SSP & 0.049 & 0.111 & 0.165 & 0.009 & $-0.483 *$ & $-0.479^{*}$ & $-0.651^{*}$ & -0.038 & 0.102 & 0.827 & 0.972 & 0.984 & 1 & \\
\hline RSC & -0.086 & 0.001 & 0.061 & 0.169 & -0.236 & 0.019 & -0.118 & 0.020 & 0.020 & 0.222 & 0.243 & 0.275 & 0.266 & 1 \\
\hline
\end{tabular}

Note: '*' represents significant at 0.05 level 
The chloride content of the water is positively significantly correlated with sodium adsorption ratio $(r=0.559)$ while positively non-significantly correlated with kelly's ratio $(\mathrm{r}=0.139)$, soluble sodium percentage $(\mathrm{r}=$ 0.102 ) and negatively non-significantly correlated with permeability index $(\mathrm{r}=$ $0.016)$. The permeability index of water is positively non-significantly correlated with Kelly's ratio $(r=0.965)$, soluble sodium percentage $(r=0.972)$. The similar results are reported with (Shashikant et al., 2015).

Due to usage of high pesticides and fertilizers by the farmers and also due to inappropriate cultivation practices there was accumulation of soluble salts which resulted moderate range of EC concentration in the samples. The $\mathrm{pH}$ was found to be acidic to neutral and all the water samples have shown low sodium hazard and alkalinity of all the water samples have shown moderately suitable for irrigation. The permeability index of water showed $66.66 \%$ of samples are not suitable for irrigation purpose and $33.33 \%$ of samples are moderately suitable. The calcium and magnesium concentration of the samples were quite high. Due to high concentration of calcium and magnesium and moderate range of soluble salts in water samples indicated poor quality irrigation water index where $62.50 \%$ of the samples were in poor range. This results shows that still improvement has to be done to improve the quality of irrigation water mainly by improving the cultivation practices. With the knowledge and experience gained through study may be developed in future to help the farmers regarding the quality of produce, high yields through soil and water conservation and better environmental protection.

\section{Acknowledgements}

The authors would like to thank the Department of Soil Science and Agricultural
Chemistry for the support. The thankfulness is also extended to all professors, friends and technicians for their continuous help and support.

\section{References}

Acharya, G.D., Solanki, M.R. and Hathi, M.V. (2010) Studies on physicochemicalparameters of irrigation water, Prantij, Gujarat (India). International Journal of Chemical Science, 8(4), 2377-2385.

APHA (1992) Standard methods for the examination of water and waste waters. American Public Health and Association, $18^{\text {th }}$ Edition, Washington.

Ayers, R.S. and Westcot, D.W. (1985) Water quality for agriculture. Rome FAO 29, 37-70.

Babiker,S., Mohamed, A. and Tetsuya Hiyama (2007) Assessing the groundwater quality using GIS. Article in Water resource management, 21(4), 699-715.

BIS (1991) Indian drinking water standards, first revision, edition 2.1.

Bryan, G., Hopkins., Donald, A., Horneck, R.G., Stevens, J., Ellsworth, W., Dan, M. and Sullivan (2007) Managing Irrigation Water Quality, for crop production in the Pacific Northwest, A Pacific Northwest Extension publication PNW 597-E.

Chapman (1996) Assessment of water quality of Gurara water transfer from Gurara dam to lower Usuma Dam for Abuja Water Supply, FCT, Nigeria. American Journal of Water Resources2(4), 74-80.

Chaudhary, V. (2018) Assessment of groundwater quality for drinking and irrigation purposes in arid areas of Rajasthan, India. Applied Water Science, 8(8), 218-235.

D.C.USDA (1954) U.S. Salinity Laboratory Staff, Diagnosis and Improvement of 
Saline and Alkali Soils. Handbook 60. Washington.

Eaton, FM. (1950) Significance of carbonate in irrigation water. Soil Science, 69, 123-133.

FAO (1994) Water quality for Agriculture (Ayers, R.S. and Westcot, D.W. Eds) FAO irrigation drainage paper, No.29, rev.1. Food and agriculture organization of the United Nations, Rome.

Gummadhi, S. (2015) Study of irrigation water quality with reference to coastal Andhra Pradesh, India. International Journal of Modern Engineering Research. 5 (4), 55-61.

Indian Council of Medical Research (ICMR) (1975) Manual of Standards of Quality for Drinking Water Supplies. Special Report Series No. 44. New Delhi: Indian Council of Medical Research.

Kumar, S., Chilukuri, D., Chandra, S., and Asadi, S.S. (2011) Assessment of ground water quality near municipal dump site and estimation of water quality index by using weighted arithmetic method tenali, Guntur
District, Andhra Pradesh, India. International Journal of Recent Technology and Engineering, 7(6C2), 2277- 3878.

Meireles, Andrade, Chaves, Frischkorn, H. and Crisostomo (2010) A new proposal of the classification of the Irrigation Water. Revista Ciencia Agronomica, 41(3), 349-357.

Richards, L.A. (1954) Diagnosis and improvement of saline and alkali soils. U.S. Salinity Laboratory Staff. USDA Handbook 60, 160.

Shashi Kant, Singh, Y.V, Lokesh Kumar Jat, Meena, R. and Singh, S.N. (2015) Assessment of ground water quality of lahar block, Bhind district in Madhya Pradesh. International Journal of Advanced Geosciences 3, 38-41.

Todd, D.K. (1980) Groundwater Hydrology, Second Edition, Wiley, New York.

World Health Organization (WHO) (2011) Guidelines for Drinking-Water Quality, WHO Press, Geneva, Switzerland, 4th edition.

\section{How to cite this article:}

PappuSrinidhi, Y. V. Singh, I. Srinath, C. Jyoshna, D. Pal and Sharma, S. 2020. Irrigation Water Quality Status of Madanapalle Block in Chittor district, Andhra Pradesh, India. Int.J.Curr.Microbiol.App.Sci. 9(06): 3530-3538. doi: https://doi.org/10.20546/ijcmas.2020.906.415 